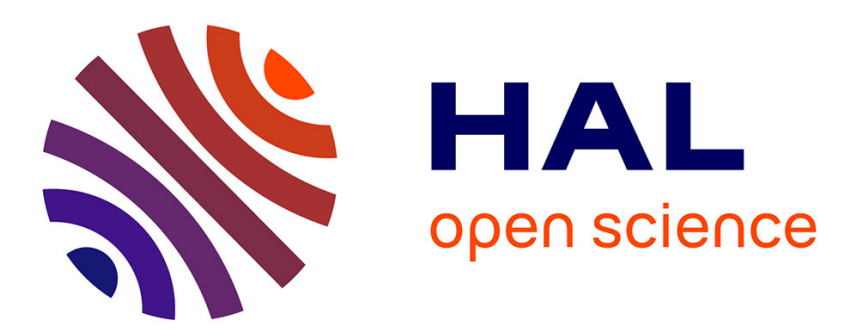

\title{
Guidelines for depth data collection in rivers when applying interpolation techniques (kriging) for river restoration
}

\author{
M. Rivas-Casado, S. White, P. Bellamy
}

\section{- To cite this version:}

M. Rivas-Casado, S. White, P. Bellamy. Guidelines for depth data collection in rivers when applying interpolation techniques (kriging) for river restoration. Hydrology and Earth System Sciences Discussions, 2007, 4 (3), pp.1069-1094. hal-00298832

\section{HAL Id: hal-00298832 \\ https://hal.science/hal-00298832}

Submitted on 16 May 2007

HAL is a multi-disciplinary open access archive for the deposit and dissemination of scientific research documents, whether they are published or not. The documents may come from teaching and research institutions in France or abroad, or from public or private research centers.
L'archive ouverte pluridisciplinaire HAL, est destinée au dépôt et à la diffusion de documents scientifiques de niveau recherche, publiés ou non, émanant des établissements d'enseignement et de recherche français ou étrangers, des laboratoires publics ou privés. 
Hydrol. Earth Syst. Sci. Discuss., 4, 1069-1094, 2007 www.hydrol-earth-syst-sci-discuss.net/4/1069/2007/

(C) Author(s) 2007. This work is licensed under a Creative Commons License.
Hydrology and Earth System Sciences Discussions

Papers published in Hydrology and Earth System Sciences Discussions are under open-access review for the journal Hydrology and Earth System Sciences

\section{Guidelines for depth data collection in rivers when applying interpolation techniques (kriging) for river restoration*}

M. Rivas-Casado, S. White, and P. Bellamy

School of Applied Sciences, Cranfield University, Cranfield, MK43 OAL, UK

Received: 12 April 2007 - Accepted: 12 April 2007 - Published: 16 May 2007

Correspondence to: M. Rivas-Casado (monica.rivascasado@gmail.com)

${ }^{*}$ Invited by M. Rivas-Casado, one of the EGU Oustanding Young Scientist Award winners 2006

Guidelines for depth data collection in rivers

M. Rivas-Casado et al.

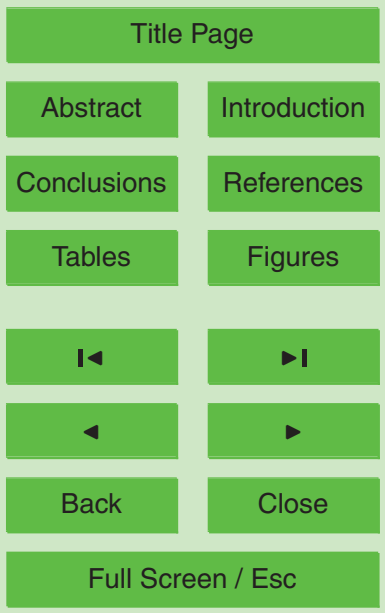

Printer-friendly Version

Interactive Discussion 


\section{Abstract}

River restoration appraisal requires the implementation of monitoring programmes that assess the river site before and after the restoration project. However, little work has yet been developed to design effective and efficient sampling strategies. Three main 5 variables need to be considered when designing monitoring programmes: space, time and scale. The aim of this paper is to describe the methodology applied to analyse the variation of depth in space, scale and time so more comprehensive monitoring programmes can be developed. Geostatistical techniques were applied to study the spatial dimension (sampling strategy and density), spectral analysis was used to study

10 the scale at which depth shows cyclic patterns, whilst descriptive statistics were used to assess the temporal variation. A brief set of guidelines have been summarised in the conclusion.

\section{Introduction}

River restoration appraisal requires the implementation of monitoring programmes to asses the status of the river before and after the development of the project. Biological, chemical, and hydromorphological (i.e. depth, substrate and velocity) variables should be monitored for this purpose.

Monitoring is time and cost consuming, this being a limitation for the implementation of all monitoring programmes. Recent studies (e.g. Rivas, 2006) and workshops (e.g. Monitoring workshop organised by the River Restoration Centre) suggest that many issues regarding the implementation of monitoring programmes need to be addressed. For example: which variables need to be sampled; definition of the frequency and sampling strategy (location and density of sampled points) of monitoring programmes and selection of the protocol to be followed for each variable (e.g. River Habitat Survey or River Continuum Survey). Even though monitoring is key to assessing the success of river restoration programmes, little work has been carried out to address the above
HESSD

4, 1069-1094, 2007

Guidelines for depth data collection in rivers

M. Rivas-Casado et al.

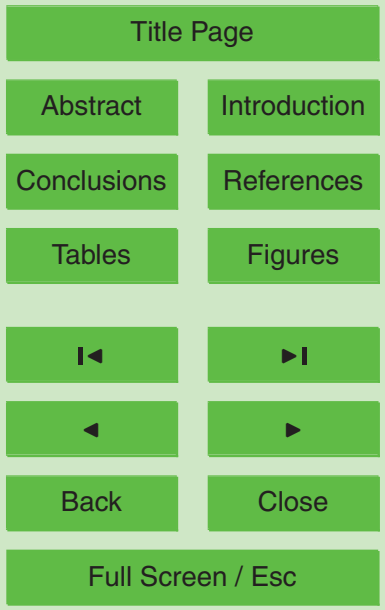

Printer-friendly Version

Interactive Discussion 
issues. This paper is part of a series dealing with design of effective and efficient sampling strategies for hydromorphological variables and focuses on the study of the spatial and temporal variability of river depth. Geostatistical and spectral analysis are used to investigate the spatial variability of depth whilst descriptive statistics are used 5 for the study of changes in depth over time.

Geostatistical analysis is an interpolation technique that can be used to estimate values of a sampled variable at locations or times where no measurements are available. This helps to reduce the number of points to be collected. There are several other methods for interpolating variables, which include techniques such as inverse o distance weighting and splines. Geostatistical analysis has the advantage of considering the variability of the variable under study whilst providing an estimation of the error associated with the predictions obtained. The variability is characterised through the calculation of the variogram, a plot that relates the distance between pairs of measured points to their variance.

15 The variogram is always associated to a specific scale of study and it is specific to each variable. It is necessary, therefore, to define at which scale or scales the variogram should be calculated in order to capture the spatial variability for river restoration assessment. This can be achieved through the assessment of pattern repetition in space. Spectral analysis is a tool that helps to identify the repetition of patterns variogram should be calculated for. Once the variogram is calculated it is possible to interpolate.

The objectives of this paper are (i) to present the methodology used to analyse the spatial and temporal variability of depth at different river sites and (ii) to provide a set of guidelines for the design of depth sampling strategies when applying geostatistical interpolation techniques. The methodology will be divided into four sections:

- Spatial pattern analysis: the sampling strategy.

- Spatial pattern analysis: the sampling density.
HESSD

4, 1069-1094, 2007

Guidelines for depth data collection in rivers

M. Rivas-Casado et al.

Title Page

Abstract

Introduction

Conclusions

Tables

References

Figures

14

- I

4

Back

Close

\section{Full Screen / Esc}

Printer-friendly Version

Interactive Discussion 
- Spatial pattern analysis: recognition of pattern repetition.

- Temporal pattern analysis.

HESSD

4, 1069-1094, 2007

\section{Data}

\subsection{Spatial pattern analysis: the sampling strategy}

Data sets of depth collected at an artificial Austrian channel were analysed for comparison of sampling strategies. Data were collected by the University of Agricultural Sciences Vienna (BOKU), Hydrology and Hydraulic Engineering, Department of Water Management. The channel was created to reproduce a natural straight stream and woody debris were included along the stream. The simulated channel is $17 \mathrm{~m}$ long, $2.5 \mathrm{~m}$ to $4 \mathrm{~m}$ width, has a $5 \%$ of slope and includes two different mesohabitats classified as riffle and pool. The topography was measured in a regular grid of dimension $5 \mathrm{~cm} \times 5 \mathrm{~cm}$. A total of 17 cross sections were identified along the reach to obtain detailed topography values. The discharge was maintained constant $\left(0.21 \mathrm{~m}^{3} \mathrm{~s}^{-1}\right)$ in steady hydraulic conditions and was regulated by a weir located at the channel end. $A$ total of 13809 depth data points were measured

\subsection{Spatial pattern analysis: the sampling density}

Fifteen river sites in the UK were analysed to investigate the effect of sampling density on the accuracy of predictions: Bere, Blackwater, Cruick. Highland Water, Lambourn, Leigh Brook (at two different discharges $Q_{80}$ and $Q_{90}$ ), Pang Fenced, Pang Unfenced
Guidelines for depth data collection in rivers

M. Rivas-Casado et al.

Title Page

Abstract

Introduction

Conclusions

References

Tables

Figures

14

4

Back

Close

Full Screen / Esc

Printer-friendly Version

Interactive Discussion Modified, Tarf and Windrush (Fig. 1 and Table 1). These rivers were selected according to the physical characteristics of the sites including characteristics at catchment and reach scale level (e.g. catchment area, stream order, substrate, discharge and 
mesohabitat types). In order to identify differences in spatial pattern between sites, a wide range of values for each specific physical descriptor were considered.

Data for each of the river sites were provided by the Centre for Ecology and Hydrology at Wallingford. Different data collection procedures and protocols were used 5 for each data set according to the type of equipment available, the purpose for which the data were collected and the field sampling conditions (e.g. accessibility and discharge). Therefore, it was necessary to standardise all the data sets in order to obtain comparable results. How this was done will be described in the methodology section.

\subsection{Spatial pattern analysis: recognition of pattern repetition}

10 The data used to investigate the scales of depth repetition that could be identified with spectral analysis was from two lowland river sites in Texas: the Brazos and the Sulphur (Table 1). Data for both river sites were collected using a single beam depth sounder.

\subsection{Temporal pattern analysis}

The data used to assess the changes in depth that occur due to changes in discharge 15

was from the Leigh Brook river site (Table 1). Data were collected at two different discharges $0.52 \mathrm{~m}^{3} \mathrm{~s}^{-1}$ and $0.34 \mathrm{~m}^{3} \mathrm{~s}^{-1}$ following a total of 200 cross-sections located $1 \mathrm{~m}$ apart in the downstream direction. Points in each cross-section were spaced by intervals of $0.5 \mathrm{~m}$. At each point depth and mesohabitat type were measured. Mesohabitat type was characterised for each cross-section according to the classification developed association of the dominant type of each cross section to the points measured. A total of 2583 georeferenced data points were measured at each flow. Points were located at the same positions at both discharges.

HESSD

4, 1069-1094, 2007

Guidelines for depth data collection in rivers

M. Rivas-Casado et al.

Title Page

Abstract

Introduction

Conclusions

References

Tables

Figures

14

$>1$

4

Back

Close

Printer-friendly Version

Interactive Discussion 


\section{Methodology}

\subsection{Spatial pattern analysis: the sampling strategy}

Five different sampling strategies derived from the original $0.5 \mathrm{~m} \times 0.5 \mathrm{~m}$ regular grid were compared: (i) random grid points were created by random selection of points 5 without replacement, (ii) stratified grids by selection of points at specific depth intervals, (iii) regular grids by dividing the sampled area into regular cells, (iv) regular transects by selection of equally spaced cross-sections and ( $v$ ) irregular transects by identifying the mesohabitats at the river sites and locating the transects at "representative" sites of these mesohabitats. An equal number of points were selected for each sampling strategy in order to obtain comparable variograms; a total of 521 points $(19.5 \%$ of the original data) were selected to create each sampling strategy. This equated to 17 transects for the transect sampling strategies. The number of points selected was determined by assessing at which sampling density a difference in the variogram shape could be observed between the five sampling strategies compared.

The variograms were calculated using the following Eq. (1):

$\gamma(\boldsymbol{h})=\frac{1}{2 N(\boldsymbol{h})} \sum_{i=1}^{N(\boldsymbol{h})}\left[z\left(\boldsymbol{u}_{i}+\boldsymbol{h}\right)-z\left(\boldsymbol{u}_{i}\right)\right]^{2}$

where $\boldsymbol{u}$ is the vector of spatial coordinates (with components $x$ and $y$ ), $z(\boldsymbol{u})$ is depth as a function of spatial location (depth at location $u$ ), $\boldsymbol{h}$ is the lag vector representing separation between two spatial locations, $z(\boldsymbol{u}+\boldsymbol{h})$ is the lagged version of depth (depth at location $\boldsymbol{u}+\boldsymbol{h}$ ) and $N(\boldsymbol{h})$ represents the number of pairs separated by a distance equal to lag $\boldsymbol{h}$ (Webster and Oliver, 2001).

The same value of minimum lag distance, azimuth and azimuth tolerance were selected for all the calculations. The variograms were calculated for each of the sampling strategies considered and compared between strategies and to the variogram obtained for the original data set. The three variogram parameters (range, sill and nugget) were
HESSD

4, 1069-1094, 2007

Guidelines for depth data collection in rivers

M. Rivas-Casado et al.

Title Page

Abstract

Introduction

Conclusions

Tables

References

Figures

14

$\rightarrow$

4

Back

Close

Full Screen / Esc

Printer-friendly Version

Interactive Discussion 


\subsection{Spatial pattern analysis: the sampling density}

Twenty different sampling densities were compared for each site. Points selected for each sampling density were obtained from a fine regular grid of $0.5 \mathrm{~m} \times 0.5 \mathrm{~m}(4$

5 points $/ \mathrm{m}^{2}$ ) created through ordinary kriging from the original data sets. The sampling densities compared were from 0.2 to 3.8 points $/ \mathrm{m}^{2}$ at intervals of 0.2 . Points for each sampling density were obtained by random selection; consecutive sampling densities included the points from the previous sampling density plus those random points required to obtain the next sampling density.

The variograms were calculated for each sampling density and used to predict depth at the points of the fine $0.5 \mathrm{~m} \times 0.5 \mathrm{~m}$ regular grid. The $0.5 \mathrm{~m} \times 0.5 \mathrm{~m}$ grid was considered to represent the real depth at each river site. The variograms obtained for each sampling strategy were used to predict depth value at all the points of the $0.5 \mathrm{~m} \times 0.5 \mathrm{~m}$ grid. The accuracy of the predictions was calculated using the following quantitative and qualitative indicators: variogram model assessment, Mean Squared Error (MSE), Mean Error (ME), descriptive statistics, frequency distribution and regression analysis. Results were compared between sampling strategies and conclusions on which sampling strategy was better for interpolation with geostatistics were established.

The indicators were calculated as follows:

- Variogram model assessment: the variogram parameters (range, sill and nugget) obtained for the predictions of each sampling strategy were compared to those obtained for the original data set.

- Mean Squared Error: The MSE was calculated as expressed in Eq. (2) where $y_{i}$ $=$ depth observed, $\hat{y}_{i}=$ depth predicted and $\mathrm{N}=$ total number of points.
HESSD

4, 1069-1094, 2007

Guidelines for depth

data collection in rivers

M. Rivas-Casado et al.

Title Page

Abstract

Introduction

Conclusions

References

Tables

Figures

14

$\rightarrow$

4

Back

Close

Full Screen / Esc

Printer-friendly Version

Interactive Discussion 
MSE $=\frac{\sum_{i=1}^{N}\left(y_{i}-\hat{y}_{i}\right)^{2}}{N}$

HESSD

- Mean Error: The mean error (ME) was calculated to provide a measure of the mean absolute difference between predicted and observed values.

$\mathrm{ME}=\frac{\sum_{i=1}^{N}\left|y_{i}-\hat{y}_{i}\right|}{N}$

5 where: $\mathrm{y}=$ depth observed; $=$ depth predicted and $\mathrm{N}=$ total number of points.

- Descriptive Statistics: maximum, minimum, mean, median, skewness, kurtosis and standard deviation were calculated for the difference between observed and predicted depth. Box plots and histograms were plotted to complete the descriptive statistics analysis.

- Frequency distribution: frequency distribution of depth can be used to characterise the diversity of features present at a river site. A two sample non-parametric test (Kolmogorov Smirnov Test) was applied in order to compare the distribution of predicted and observed depth values.

- Regression analysis: a linear model was fitted for the predicted and observed depth. The coefficient of determination or r-squared quantified the proportion of variation explained by the model created (Montgomery et al., 2001) indicating how similar predicted and observed values were. The slope and the intersection value of the regression line were also examined.

3.3 Spatial pattern analysis: recognition of pattern repetition

20 Spectral analysis can be used to recognise a cyclical pattern in series of data by applying a modification of Fourier analysis (Chatfield, 1996), which is based on approx-

Guidelines for depth data collection in rivers

M. Rivas-Casado et al.

Title Page

Abstract Introduction

Conclusions References

Tables Figures

14

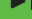

4

Back

Close

Printer-friendly Version

Interactive Discussion 
imating a function by a sum of sine and cosine terms, called the Fourier series representation. The periodogram, which is the result of the spectral analysis, provides information on the pattern of variation of the data set in the spectral domain (Webster and Oliver, 2001). The spectrum and the variogram are complementary ways of 5 viewing the spatial/temporal periodicity and estimating the period.

The calculation of the periodogram requires input values equally spaced and distributed along a longitudinal line. Since data collected did not meet these requirements, the variogram was used to predict depth values at the appropriate locations. The spherical model was used for this purpose, with a minimum lag distance equal to $1.5 \mathrm{~m}$ and 10 azimuth tolerance of $60^{\circ}$. Depth values were predicted at three longitudinal profiles at each river site separated by $5 \mathrm{~m}$ intervals for the Sulphur and $10 \mathrm{~m}$ for the Brazos site. Points were predicted every $20 \mathrm{~m}$ along each longitudinal profile. Periodic cycles at distances smaller than $20 \mathrm{~m}$ were not considered within the scope of this study.

The Brazos river site was divided into reaches of $2000 \mathrm{~m}$ in length so that similar 15 lengths were analysed for the Sulphur and Brazos river sites. A total of three different reaches, with three different longitudinal profiles each were analysed for the Brazos site.

The periodogram, which is a measure of smoothness of the periodogram function, was computed for several bandwidths (i.e. 1, 10, 20, and 50). The higher the bandwidth, the less detail was provided by the periodogram. Bandwidth 1 represents the raw periodogram, without smoothing. The bandwidth needs to be narrower than the features that one wishes to reveal (Webster and Oliver, 2001). Choosing a bandwidth of 10 showed the principal features of the periodogram most clearly (the information provided by the raw periodogram was too detailed). The estimated periodogram was 25 judged rather too smooth when using bandwidths above 20.

\subsection{Temporal pattern analysis}

The number of points identified for each mesohabitat type within the Leigh Brook site was obtained for each discharge. Those points that changed mesohabitat type be-
HESSD

4, 1069-1094, 2007

Guidelines for depth

data collection in rivers

M. Rivas-Casado et al.

Title Page

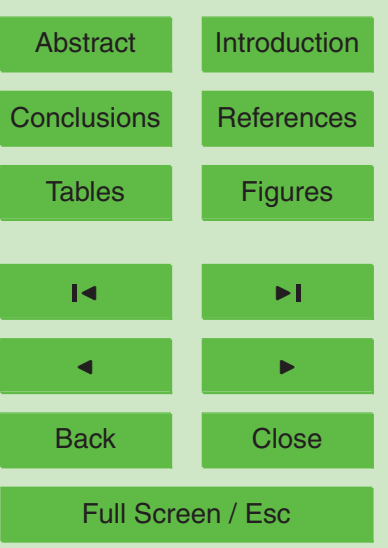

Printer-friendly Version

Interactive Discussion 
tween discharges were identified. Conclusions were established on the types of mesohabitat that were more sensitive to changes in discharge and what sequence the types of mesohabitats followed when decreasing the discharge. Depth change was calculated as the difference between depth at $Q=0.52 \mathrm{~m}^{3} \mathrm{~s}^{-1}$ minus depth measured at $Q$ $5=0.34 \mathrm{~m}^{3} \mathrm{~s}^{-1}$; positive and negative depth changes indicate increase and decrease in depth, respectively. The Least Squares (LS) means plot of depth change vs. mesohabitat type was calculated for the standardized values of depth change. Results showed which mesohabitat types presented higher changes in depth when decreasing the discharge.

\section{Results}

\subsection{Spatial pattern analysis: the sampling strategy}

Results showed that variograms obtained for grid sampling strategies were more similar to the original data set than those variograms obtained with transect sampling strategies. Figure 2 shows an example of the variograms obtained for the original grid, a random grid sampling strategy and regular transect sampling strategies. The variogram parameters for the example have been summarised in Table 2. Points in the experimental variogram for transect sampling strategies were not distributed homogeneously for all the lag distances observed (e.g. Fig. 2) but were distributed according to the distances between transects. Although this did not have an effect on the variogram 20 pait parameters in Table 2, difficulties were encountered when trying to predict depth at non sampled locations with transect sampling strategies. The problem was that the location of the transects left areas without neighbours to obtain predictions, thus decreasing the accuracy of the predictions.

The choice between grid and transect sampling strategies needs to be understood 25 as a trade off between the number of points that are included in the experimental variogram and the number of pairs of points separated by a specific lag distance. Transect
HESSD

4, 1069-1094, 2007

Guidelines for depth data collection in rivers

M. Rivas-Casado et al.

Title Page

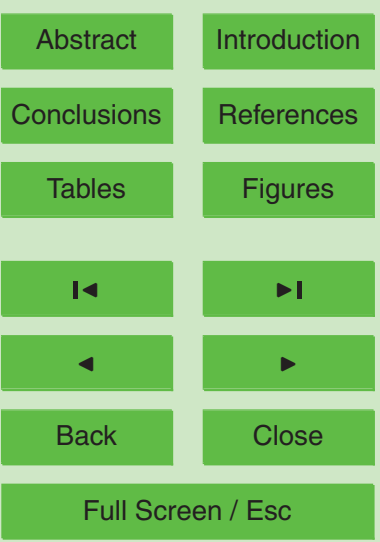

Printer-friendly Version

Interactive Discussion 
sampling strategies provided less number of points in the variogram but more accurate values of semivariance for each of these points since a larger number of pairs of points are included in the calculation of the semivariance of each lag distance. On the other hand, grid sampling strategies provided a larger number of variogram points but a less 5 accurate value of semivariance for each of these points. This is why in Fig. 2 the scale of the semivariance identified for grid sampling strategies is larger than that identified for transect sampling strategies (Table 2).

\subsection{Spatial pattern analysis: the sampling density}

The general pattern showed that the discrepancy in representing each river site increased with decreasing sampling density and that the sampling density at which the discrepancy started to increase differed according to the indicator considered (Fig. 3). Thus, it could be observed that different sampling densities should be applied for different sampling objectives (indicators).

Results also showed that the accuracy of the predictions depended on the river site analysed but it was not possible to define a clear and constant relationship for the river sites. Thus, for example for the MSE between predicted and observed values (Fig. 3), the rivers with highest errors were the Bere, the Pang Fenced and the Blackwater, in decreasing order. In contrast, different results were obtained when considering the $p$ value (Fig. 3); the rivers with higher accuracy using this indicator were the Blackwater, the Leigh Brook, the Pang Fenced and the Tame Highly Modified in descending order.

\subsection{Spatial pattern analysis: recognition of pattern repetition}

Peaks in the periodogram were identified from sampled lengths of $20 \mathrm{~m}$ up to the total sampled length. Figure 4 and Table 3 summarises the frequencies at which the peaks where identified, the corresponding wavelength (number of sampling intervals), and the extension of the cycle in terms of sampled river length, for one of the longitudinal profiles analysed for the Sulphur site. The sampling interval of the periodogram cor-
HESSD

4, 1069-1094, 2007

Guidelines for depth data collection in rivers

M. Rivas-Casado et al.

Title Page

Abstract

Introduction

Conclusions

Tables

References

Figures

14

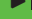

4

Back

Close

Printer-friendly Version

Interactive Discussion 
responds to $20 \mathrm{~m}$. Frequency was transformed into sampled length through Eq. (4), where $L$ is the length of the cycle $(m)$ and $F$ is the frequency.

$L=20 \times\left(\frac{1}{F}\right)$

Results indicated that it was possible to recognise specific spatial occurrences for the 5 longitudinal profiles analysed but that these occurrences were not common to both river sites. For the Brazos site, depth seemed to follow a pattern of repetition every $750 \mathrm{~m}, 500 \mathrm{~m}, 170 \mathrm{~m}$ and $110 \mathrm{~m}$. Cycles of repetition could also be observed at smaller scales but they were not consistent between the analysed longitudinal profiles. For the Sulphur river site it was possible to identify common patterns of repetition of depth at $10350 \mathrm{~m}, 87 \mathrm{~m}$ and $60 \mathrm{~m}$.

\subsection{Temporal pattern analysis}

Four mesohabitat types were identified at the Leigh Brook site: riffle, shallow glide, deep glide and pool. The four of them appeared in both discharges. At $Q=0.34 \mathrm{~m}^{3} \mathrm{~s}^{-1}$ shallow glides (1284 points) and riffles (844 points) were the dominant types, whilst pool and deep glides represented $11 \%$ (313 points) and 4.4\% (124 points) respectively. Similar results were obtained at $\mathrm{Q}=0.52 \mathrm{~m}^{3} \mathrm{~s}^{-1}$ since only $9 \%$ of the data points $(254$ points) changed their mesohabitat type. Table 4 shows the percentage of points that changed from one mesohabitat type to another when decreasing the discharge. The majority of habitats that changed were transformed into shallow glides, those changes being more frequent from deep glides. Table 5 summarises the descriptive statistics obtained for depth change variable.

Figure 5 shows the LS means plot (plot of the least squares means which are the best linear-unbiased estimates of the marginal means for the design) obtained for the standardised parameters included in this analysis. The LS mean plot of depth change vs. mesohabitat showed that depth changes were significantly different between deep glides and shallow glides (deep glides having the greater depth changes), whilst pools

Guidelines for depth data collection in rivers

M. Rivas-Casado et al.

Title Page

Abstract

Introduction

Conclusions

Tables

References

Figures

14

4

Back

Close

Printer-friendly Version

Interactive Discussion 
and riffles were not significantly different. Deep glides could not be considered significantly different to riffles and pools, whilst shallow glides represented differences from both, riffles and pools. The mean depth changes were located between $0.037 \mathrm{~m}$ (riffles) and $0.048 \mathrm{~m}$ (shallow glide). Table 6 summarises the depth change encountered 5 for each mesohabitat type.

\section{Conclusions}

It is recommended that grid sampling strategies are used when characterising the spatial pattern of depth rather than any type of transect sampling strategy since for transect sampling (i) difficulties are encountered when predicting the variable at non measured 10 locations due to the lack of neighbouring points and (ii) the variogram structure is conditioned by the location of the transects. Furthermore, for transect sampling strategies (i) there is not a clear criteria for the placement of the transects, (ii) it is difficult to sample data along an exact perpendicular to the channel discharge and so, it is necessary to visually mark the transect and (iii) there is a higher cost associated than for grid sampling strategies since it is necessary to visually mark the transects.

The use of random grids is preferred to the use of stratified and regular grids since (i) results obtained for random grids do not significantly differ from those obtained with regular grids and (ii) random sampling strategies (i.e. random walk) are less time consuming sampling strategies. Similarly to transect sampling strategies, regular grids require visual marks to determine the corners of each cell in the grid, this increasing the time expended in the data collection procedure. Instead, random sampling strategies (i.e. random walk), can be applied whilst randomly walking along the river channel, without requiring the visually marking of areas where data need to be collected. Furthermore, data can be collected at those locations that provide detail information on

noted that it is more difficult to replicate measurements at the same locations over time when random sampling strategies are applied.
HESSD

4, 1069-1094, 2007

Guidelines for depth

data collection in rivers

M. Rivas-Casado et al.

Title Page

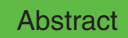

Introduction

Conclusions

Tables

References

Figures

14

-1

4

Back

Close

Printer-friendly Version

Interactive Discussion

EGU 
Sampling density needs to be selected according to the objective for which the data are being collected. A set of tables relating the accuracy obtained in the predictions when applying a specific sampling density has been developed. These tables were calculated considering a regular grid of $0.5 \mathrm{~m} \times 0.5 \mathrm{~m}$ as a real and accurate repre5 sentation of the reach. Predictions were obtained at each point of the $0.5 \mathrm{~m} \times 0.5 \mathrm{~m}$ regular grid. The accuracy of the predictions was measured through different indicators (e.g. mean squared error and frequency distribution). Further research needs to determine which indicator is most suitable to define the sampling strategy for a specific objective (e.g. river restoration or habitat assessment). In general, when defining the 10 sampling strategy for a reach it is necessary to consider that the higher the hydromorphological uniformity and continuity of the river site, the lower the sampling density that needs to be applied.

The variogram is a tool that can be used to understand the spatial pattern of a variable under study. However its calculation needs to be accompanied by a sensitivity 15 anc analysis that considers the variogram model selected, the number of pairs of points, the minimum lag distance selected, the maximum distance used, the azimuth tolerance and the azimuth direction. Otherwise, variogram results could be misleading.

Results suggest that the repetition of the depth spatial pattern might not correspond to a fixed sampling distance across all rivers but needs to be defined according to the characteristics of each river site. Repetition in the characteristics of river depth have been encountered at distances equal to $500 \mathrm{~m}, 350 \mathrm{~m}$ and $150 \mathrm{~m}$ for the two river sites analysed.

Discharge decrements mainly transformed deep areas (deep glides and pools) into shallower and less smooth habitats (shallow glides). Largest depth changes for the riffles.

Acknowledgements. I would like to thanks: I. Maddock from University of Worcester for providing the data set collected at the Leigh Brook river site; $\mathrm{H}$. Mader from University of Agricultural Sciences Vienna (BOKU) for providing the data set collected at the simulated Austrian channel;

\section{HESSD}

4, 1069-1094, 2007

\section{Guidelines for depth data collection in rivers}

M. Rivas-Casado et al.

Title Page

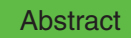

Introduction

Conclusions

Tables

References

Figures

I

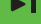

4

Back

Close

\section{Full Screen / Esc}

Printer-friendly Version

Interactive Discussion 
and V. Merwade from Purdue University and Texas Water Development Board for providing the data sets collected at the Sulphur and Brazos river sites. I would also like to thanks the Centre for Ecology and Hydrology at Wallingford.

\section{HESSD}

4, 1069-1094, 2007

\section{References}

Chatfield, C.:The analysis of time series: an introduction. Texts in Statistical Science., 5th ed. London: Chapman \& Hall/CRC, 1996.

Maddock, I. P. and Bird, D.: The application of habitat mapping to identify representative PHABSIM sites on the river Tavy, Devon, UK, in: Procedings of the 2nd International Symposium on Habitats and Hydraulics, edited by: Leclerc, M., Capra, H., Valentin, S., Boudreault, A., and Cote, Y., Quebec city, Canada, I, 203-215, 1996.

Montgomery, D. C., Peck, E. A., and Vining, G. G. (Eds.): Introduction to linear regression analysis, Third ed. United States of America., John Wiley \& Sons, INC, 2001.

Webster, R. and Oliver, M. Geostatistics for Environmental Scientists. Series: Statistics in Practice, Wiley, Chichester, 2001.

15 Rivas Casado, M.:The use of geostatistics for hydromorphological assessment in rivers. Thesis (Ph.D) thesis, Cranfield University at Silsoe. Notes: 280 p + CD-ROM, Supervisor: S. F. White, 2006.

\section{Guidelines for depth data collection in rivers}

M. Rivas-Casado et al.

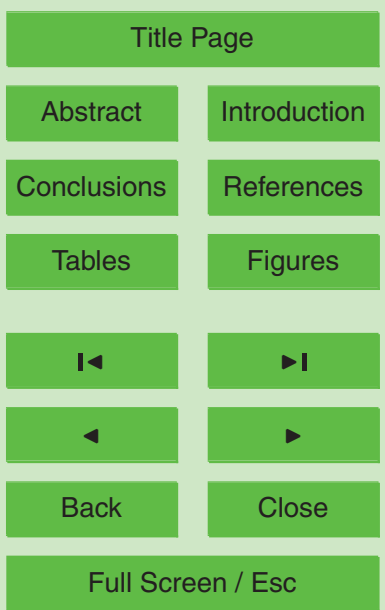

Printer-friendly Version

Interactive Discussion 


\section{HESSD}

4, 1069-1094, 2007

Guidelines for depth data collection in rivers

Table 1. River sites analysed (HM and LM refer to Highly Modified and Low Modified, respectively).

\begin{tabular}{|c|c|c|c|c|c|c|}
\hline River site & Location & Reach Length (m) & Sampled points & Mean width (m) & $\begin{array}{l}\text { Sampled discharge } \\
\mathrm{m}^{3} \mathrm{~s}^{-1}\end{array}$ & Low Flows 2000 \\
\hline Artificial Austrian channel & Vienna, Austria, & 17 & 13809 & 3 & 0.21 & - \\
\hline Brazos & Texas, USA & 7500 & 37288 & 100 & - & - \\
\hline Bere & Dorset, UK. & 80 & 924 & 5.8 & 0.36 & 79 \\
\hline Blackwater & Surrey, UK & 155 & 4529 & 5.8 & 0.46 & 33 \\
\hline Cruick & North East Scotland & 246 & 2382 & 5.6 & 0.61 & 51 \\
\hline Highland Water & Hampshire, UK & 50 & 219 & 4 & 0.09 & 43 \\
\hline Lambourn & Berkshire, UK & 46 & 2200 & 7.5 & 0.67 & 92 \\
\hline Leigh Brook & Gloucestershire, UK & 200 & 2983 & 8.1 & 0.34 and 0.52 & 93 and 82 \\
\hline Pang Fenced & Berkshire, UK & 110 & 700 & 5.5 & 0.27 & 91 \\
\hline Pang Unfenced & Berkshire, UK & 107 & 784 & 6.7 & 0.27 and 0.32 & 90 and 80 \\
\hline Pang Old Fenced & Berkshire, UK & 30 & 299 & 5 & 0.27 and 0.32 & 90 and 80 \\
\hline Senni & Brecon, Wales & 40 & 894 & 8.8 & 0.44 & 78 \\
\hline Sulphur & Texas, USA & 1500 & 8490 & 35 & - & - \\
\hline Tame HM & Birmingham, UK & 93 & 1278 & 12 & 2.52 & 20 \\
\hline Tame LM & Birmingham, UK & 142 & 957 & 9.5 & 1.46 & 43 \\
\hline Tarf & North East Scotland & 212 & 5045 & 5.5 & 0.34 & 50 \\
\hline Windrush & Gloucestershire & 126 & 810 & 9.7 & - & - \\
\hline
\end{tabular}

M. Rivas-Casado et al.

Title Page

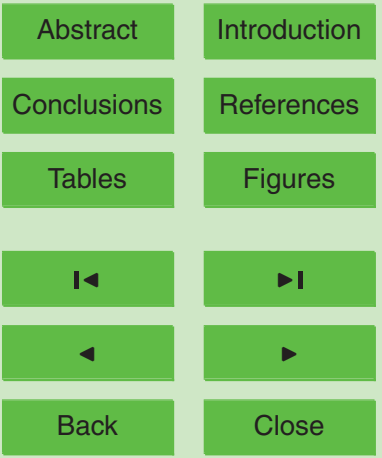

Full Screen / Esc

Printer-friendly Version

Interactive Discussion 


\section{HESSD}

4, 1069-1094, 2007

\section{Guidelines for depth} data collection in rivers

M. Rivas-Casado et al.

Table 2. Example of variogram parameters obtained for the original data set and two sampling strategies compared at the artificial Austrian channel.

\begin{tabular}{llllll}
\hline Data set & Number of points & Range $(\mathrm{mm})$ & Sill & Nugget & Objective \\
\hline Original & 10130 & 2492.7 & 32894.7 & 0 & 3772196483.2 \\
Random grid & 521 & 2480.1 & 39010.5 & 0 & 17776958526.7 \\
Regular transect & 521 & 2199.8 & 35547.6 & 0 & 15123745877.6 \\
\hline
\end{tabular}

Title Page

Abstract

Introduction

Conclusions

References

Tables

Figures

14

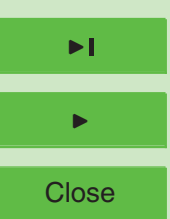

Back

Close

Full Screen / Esc

Printer-friendly Version

Interactive Discussion 


\section{HESSD}

4, 1069-1094, 2007

\section{Guidelines for depth} data collection in rivers

M. Rivas-Casado et al.

Table 3. Cycle, wavelength and distance at which the peaks in the periodogram were identified. Point number refers to the points of each peak identified in Fig. 4.

\begin{tabular}{llll}
\hline Point number & Cycle & Wavelength & Distance $(\mathrm{m})$ \\
\hline 1 & 0.05714 & 17.50 & 350.0 \\
2 & 0.1285 & 7.78 & 155.5 \\
3 & 0.2285 & 4.37 & 87.5 \\
4 & 0.3285 & 3.04 & 60.8 \\
\hline
\end{tabular}

Title Page

Abstract

Introduction

Conclusions

References

Tables

Figures

14

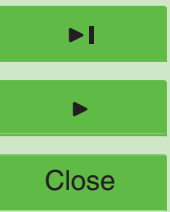

Back

Close

Full Screen / Esc

Printer-friendly Version

Interactive Discussion 


\section{HESSD}

4, 1069-1094, 2007

\section{Guidelines for depth} data collection in rivers

M. Rivas-Casado et al.

Table 4. Percentage of points that changed mesohabitat type from $Q=0.52 \mathrm{~m}^{3} \mathrm{~s}^{-1}$ to $Q=$ $0.34 \mathrm{~m}^{3} \mathrm{~s}^{-1}$ at the Leigh Brook river site.

\begin{tabular}{llllll}
\hline & & \multicolumn{4}{c}{ Original Situation $\mathrm{Q}=0.52 \mathrm{~m}^{3} \mathrm{~s}^{-1}$} \\
& & Deep Glide & Pool & Riffle & Shallow Glide \\
\hline Final Situation & Deep Glide & 58 & - & - & - \\
$\mathrm{Q}=0.34 \mathrm{~m}^{3} \mathrm{~s}^{-1}$ & Pool & - & 90 & - & - \\
& Riffle & 3 & - & 97 & 6 \\
& Shallow glide & 39 & 10 & 3 & 94 \\
\hline
\end{tabular}

Title Page

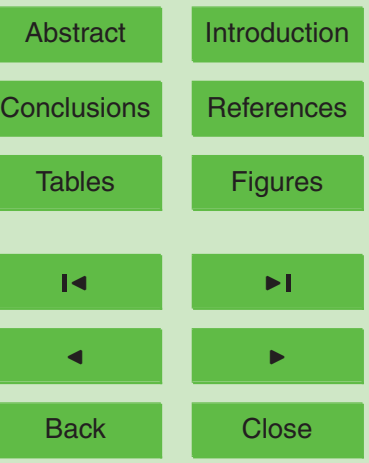

Full Screen / Esc

Printer-friendly Version 


\section{HESSD}

4, 1069-1094, 2007

\section{Guidelines for depth} data collection in rivers

M. Rivas-Casado et al.

Table 5. Descriptive statistics for depth measured at the Leigh Brook river site. Positive changes indicated an increase of the value of the parameter and negative changes a decrease.

\begin{tabular}{llllllll}
\hline Parameter & Mean & Median & Minimum & Maximum & Std.Dev. & Skewness & Kurtosis \\
\hline Depth Change $(\mathrm{m})$ & -0.039 & -0.04 & -0.50 & 0.58 & 0.06 & 0.5 & 7.9 \\
Depth 1st Flow $(\mathrm{m})$ & 0.245 & 0.21 & 0.00 & 0.94 & 0.15 & 0.8 & 0.7 \\
Depth 2nd Flow $(\mathrm{m})$ & 0.206 & 0.18 & 0.00 & 0.85 & 0.15 & 0.8 & 0.4 \\
\hline
\end{tabular}

Title Page

Abstract Introduction

Conclusions References

Tables Figures

14 $>$ I

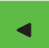

Back

Close

Full Screen / Esc

Printer-friendly Version

Interactive Discussion 


\section{HESSD}

4, 1069-1094, 2007

\section{Guidelines for depth} data collection in rivers

M. Rivas-Casado et al.

Table 6. Descriptive statistics for depth change grouped by mesohabitat type encountered at discharge $=0.52 \mathrm{~m}^{3} \mathrm{~s}^{-1}$ at the Leigh Brook river site. Non-standardised parameters.

\begin{tabular}{lllll}
\hline Descriptive Statistic & Shallow glide & Riffle & Pool & Deep glide \\
\hline Absolute Mean $(\mathrm{m})$ & 0.048 & 0.037 & 0.039 & 0.026 \\
Absolute Maximum $(\mathrm{m})$ & 0.33 & 0.37 & 0.58 & 0.19 \\
Std. Dev. & 0.05 & 0.053 & 0.07 & 0.048 \\
\hline
\end{tabular}

Title Page

Abstract

Introduction

Conclusions

References

Tables

Figures

I

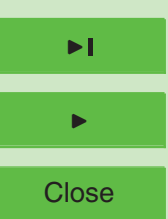

Back

Close

Full Screen / Esc

Printer-friendly Version

Interactive Discussion 


\section{HESSD}

4, 1069-1094, 2007

Guidelines for depth data collection in rivers

M. Rivas-Casado et al.

Title Page

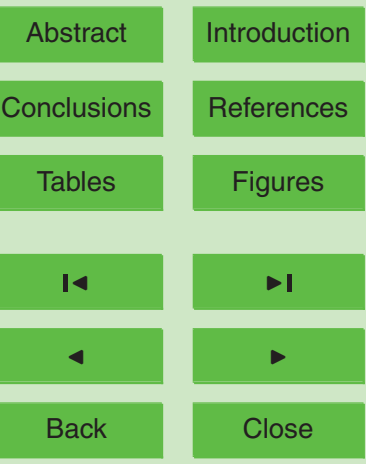

Full Screen / Esc

Printer-friendly Version

Interactive Discussion 


\section{HESSD}
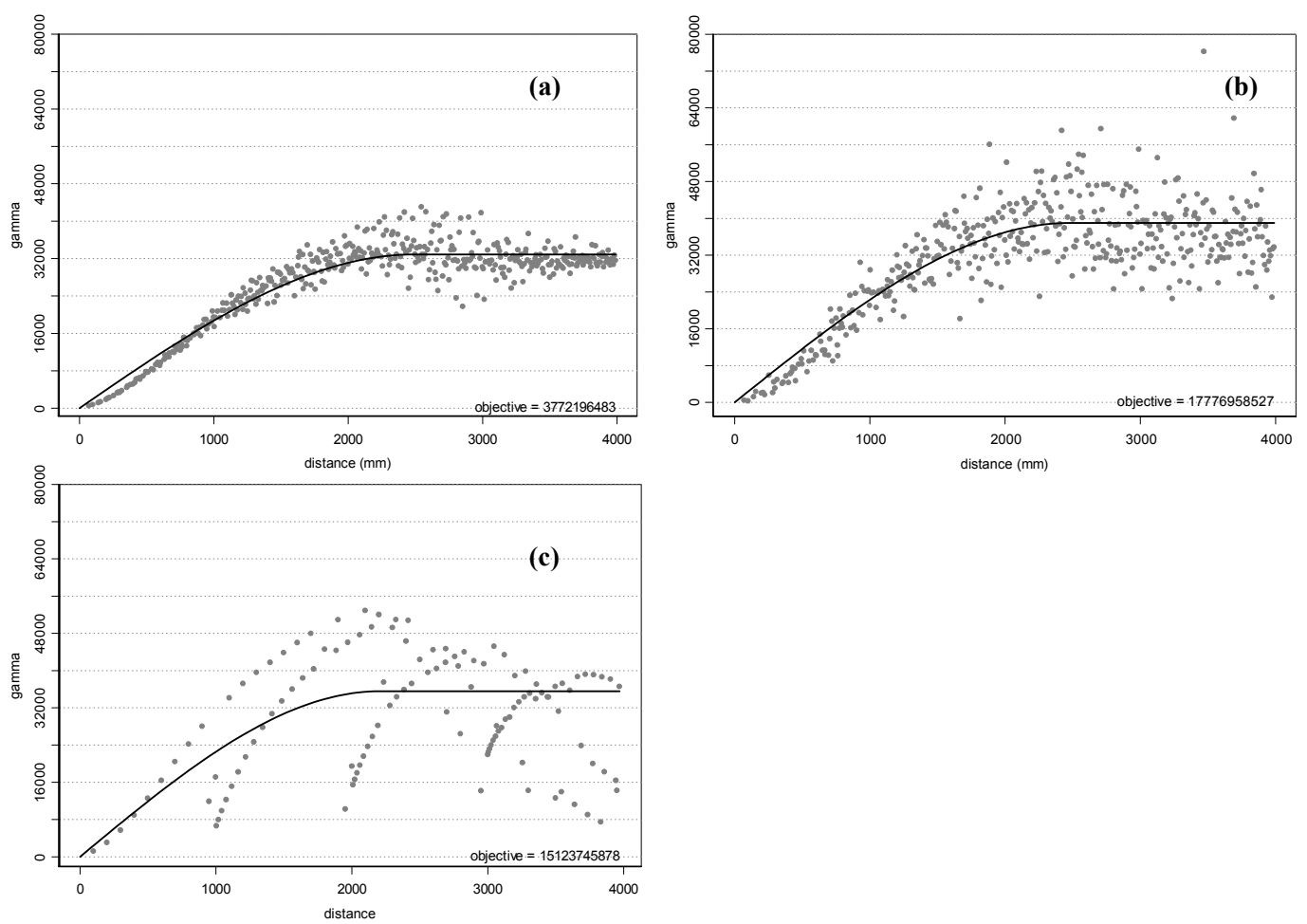

Fig. 2. Experimental (grey dots) and empirical (fitted line) variograms obtained for two different sampling strategies: (a) original data set, (b) random grid and (c) regular transects.

\section{4, 1069-1094, 2007}

\section{Guidelines for depth} data collection in rivers

M. Rivas-Casado et al.

Title Page

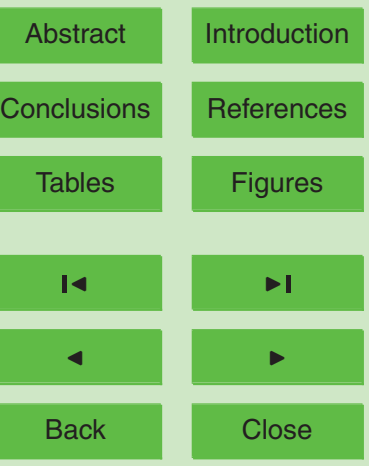

Full Screen / Esc

Printer-friendly Version

Interactive Discussion 

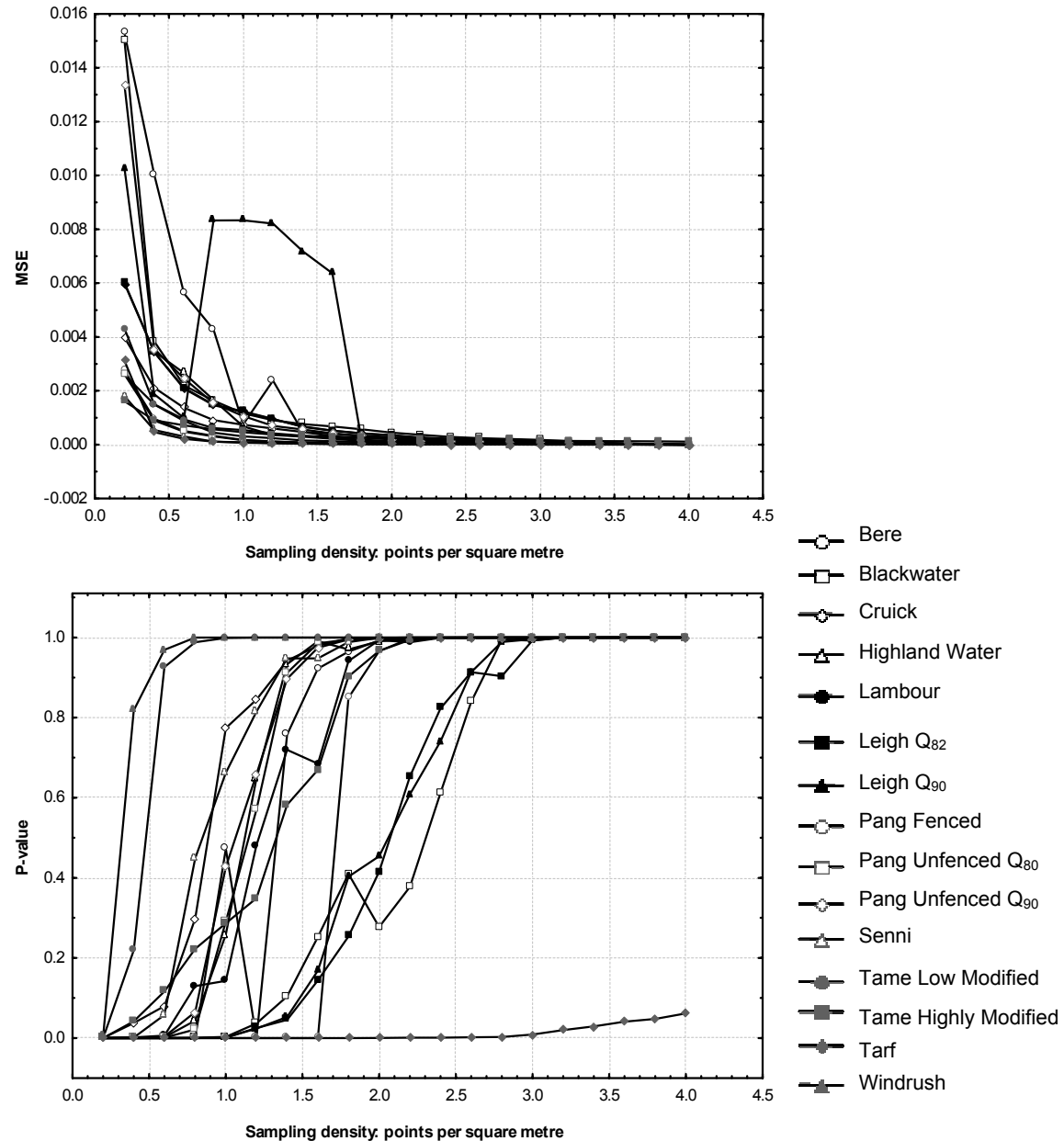

\section{HESSD}

4, 1069-1094, 2007

Guidelines for depth data collection in rivers

M. Rivas-Casado et al.

Title Page

Abstract

Introduction

Conclusions

References

Tables

Figures

14

I

4

Back

Close

\section{Full Screen / Esc}

Printer-friendly Version

Interactive Discussion

Fig. 3. Mean Squared Error (upper) and p-value (lower) for 20 different sampling densities and 15 sites. 
HESSD

4, 1069-1094, 2007

\section{Guidelines for depth} data collection in

rivers

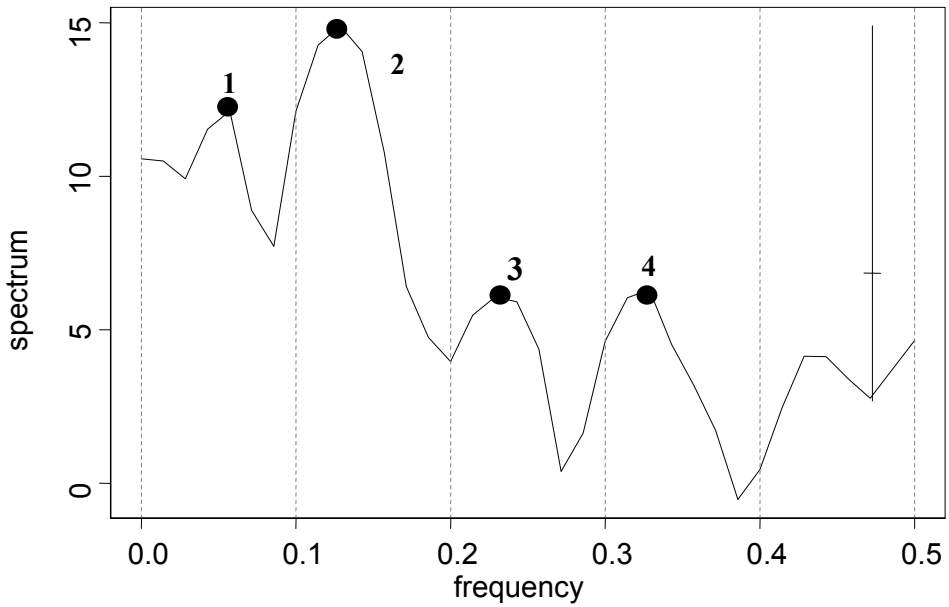

Fig. 4. Periodogram obtained for one of the longitudinal profiles analysed in the Sulphur river site. Values on Table 3 show the cycle, wavelength and distance at which each peak has been identified.
M. Rivas-Casado et al.

Title Page

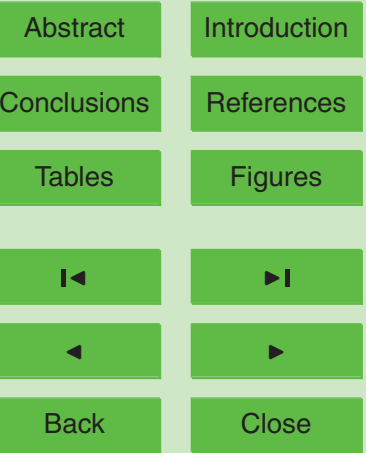

Full Screen / Esc

Printer-friendly Version

Interactive Discussion 


\section{HESSD}

4, 1069-1094, 2007

\section{Guidelines for depth}

data collection in rivers

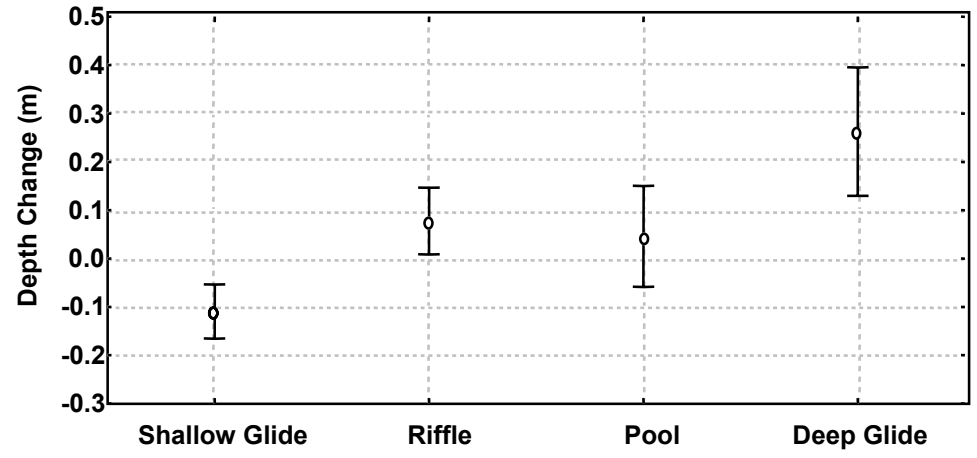

Fig. 5. Mean plots with 0.95 confidence interval obtained for the standardised parameters. Vertical lines denote the $95 \%$ confidence interval. The types represented correspond to those encountered at discharge $0.34 \mathrm{~m}^{3} \mathrm{~s}^{-1}$.
M. Rivas-Casado et al.

Title Page

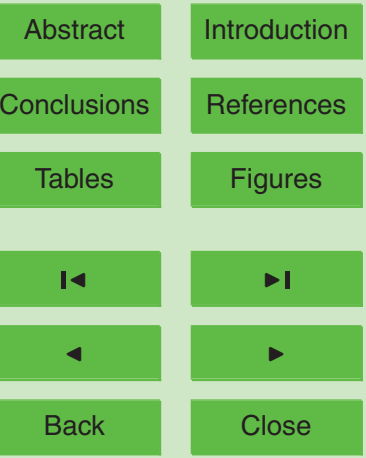

Full Screen / Esc

Printer-friendly Version

Interactive Discussion 